\title{
Macrophage infiltration precedes and is a prerequisite for lymphocytic insulitis in pancreatic islets of pre-diabetic BB rats
}

\author{
H. Hanenberg ${ }^{1}$, V. Kolb-Bachofen ${ }^{2}$, G. Kantwerk-Funke ${ }^{1}$ and H. Kolb ${ }^{1}$ \\ ${ }^{1}$ Diabetes Research Institute, and ${ }^{2}$ Institute for Biophysics and Electron Microscopy, University of Düsseldorf, FRG
}

Summary. We have analysed whether infiltration of macrophages and lymphocyte subtypes into pancreatic islets of diabetes prone BB rats occurs at random or whether insulitis requires a specific sequence of events. Serial sections from more than 700 islets of diabetes prone BB rats (70-150 days of age) were analysed for infiltrating immunocytes and expression of major histocompatibility complex antigens by 4-11 different monoclonal antibodies. In parallel, electron microscopy was performed in a fraction of islets. Part of the animals had been treated with macrophage toxic silica particles. A specific non-random sequence of events was identified and 4 stages of islet inflammation were recognised. Stages $1 \mathrm{a}$ and $1 \mathrm{~b}$ are defined by macrophage (ED ${ }^{+}, \mathrm{W} 3 / 25^{+} . \mathrm{Ox} 3 / 6 / 17^{+}$, $\mathrm{ED} 2^{-}$) infiltration and concomitant enhanced major histocompatibility complex class I antigen expression initially at one pole or at the periphery of islets. T-, NK- and B-lymphocytes are absent ( $<1$ cell per mean islet section). In stage 2 , more macrophages are infiltrating and concomitantly $\mathrm{Ox} 19^{+}$T-lymphocytes and $\mathrm{Ox} 8^{+}$-granular (NK-) lymphocytes are observed. In stage 3 , additional massive infiltration of $\mathrm{Ox} 12^{+}$B-lymphocytes is noted. Silica treatment of BB rats largely prevented macrophage infiltration. Concomitantly islets were free of lymphocytes. Thus, macrophage infiltration clearly precedes T- and NK-lymphocyte and later B-lymphocyte infiltration. Lymphocytes do not infiltrate islets in the absence of prior macrophage invasion.

Key words: BB rats, insulitis, macrophages, T-lymphocytes, silica, electron microscopy.
The spontaneous occurrence of insulin-dependent diabetes in BB rats is preceded by mononuclear infiltration of pancreatic islets [1]. The prevention of diabetes by neonatal thymectomy or by depletion of $\mathrm{Ox}-19^{+}$. lymphocytes demonstrates the T-cell dependency of the disease process $[2,3]$. Further support comes from cell transfer experiments where insulitis and diabetes was observed in normal cyclophosphamide treated WistarFurth rats after injection of concanavalin-A-stimulated spleen cells from acutely diabetic BB rats [4].

On the other hand, administration of silica particles, a product toxic to macrophages, almost completely prevented manifestation of diabetes in BB rats $[5,6]$. Ultrastructural studies demonstrated an early phase of islet inflammation where single macrophages were seen infiltrating islets with concomitant islet cell destruction, termed "single cell insulitis" $[7,8]$. These findings indicate an essential role of macrophages, as well as of $\mathrm{T}$ lymphocytes in the pathogenesis of diabetes in BB rats. In the present study, we have analysed whether macrophages, T-lymphocytes, natural killer cells and B-lym- phocytes contribute to islet inflammation in a specific sequence, or whether there is a random infiltration of islets by immune cells. For this purpose, we performed a semiquantitative analysis of islet infiltration in prediabetic BB rats.

\section{Material and methods}

\section{Animals}

BB rats came from our colony which is derived from breeding pairs kindly provided by Dr. A. A. Like, University of Massachusetts, Worcester, Mass., USA. The breeding nucleus of Wistar rats came from Zentralinstitut für Tierzucht, Hannover, FRG. Of 11 BB rat litters, 49 rats were allocated into sex and litter matched groups. One group was treated with silica particles $(100 \mathrm{mg}$ per $\mathrm{kg}$ body weight, SteinkohleBergbau-Verein, Essen, FRG) at 50, 55, 60 and 70 days of age as described previously $[5,6]$. The control group remained untreated. The incidence rate of diabetes in our colony is $60-80 \%$ by 150 days of age.

Rats were weighed twice weekly and checked daily for glucosuria and ketonuria. Criteria of diabetes were weight loss and confirmed hyperglycaemia above $11 \mathrm{mmol}$ glucose/1 (Glukoquant, Boehringer, 
Table 1. List of monoclonal antibodies

\begin{tabular}{|c|c|c|c|}
\hline Antibody & IgG class & Specifity & References \\
\hline $\mathrm{MRC} \mathrm{OX}-6^{\mathrm{a}}$ & IgG1 & Rat class II (I-A) major histocompatibility antigen & [9] \\
\hline $\mathrm{MRC} \mathrm{OX}-8^{\mathrm{a}}$ & IgG1 & $\begin{array}{l}\text { Rat CD8 antigen on cytotoxic/suppressor lymphocytes } \\
\text { peripheral lymphocytes, thymocytes } \\
\text { natural killer cells }\end{array}$ & $\begin{array}{l}{[10]} \\
{[11]} \\
{[12]}\end{array}$ \\
\hline $\operatorname{MRC~OX}-12^{\mathrm{a}}$ & $\operatorname{IgG} 2 \mathrm{a}$ & Rat immunoglobulin kappa chain & [13] \\
\hline $\mathrm{MRC} O X-17^{\mathrm{a}}$ & IgG1 & Rat class II (I-E) major histocompatibility antigen & [14] \\
\hline $\mathrm{W} 3 / 13^{\mathrm{a}}$ & $\operatorname{IgG1}$ & $\begin{array}{l}\text { Leukocyte sialoglycoprotein on peripheral T cells, } \\
\text { thymocytes, polymorphs, plasma cells } \\
\text { natural killer cells }\end{array}$ & {$[16]$} \\
\hline $\mathrm{W} 3 / 25^{\mathrm{a}}$ & $\operatorname{IgG} 1$ & $\begin{array}{l}\text { Rat CD4 antigen on helper } T \text { cells } \\
\text { thymocytes } \\
\text { macrophages }\end{array}$ & $\begin{array}{l}{[16]} \\
{[17]} \\
{[18]}\end{array}$ \\
\hline
\end{tabular}

${ }^{a}$ Camon Serotec, Wiesbaden, FRG; ${ }^{b}$ kind gift by Dr. CD Dijkstra, Department of Histology, Free University, Amsterdam, The Netherlands

Mannheim, FRG). Groups of non-diabetic animals were killed at 70, $90,120,133$ and 150 days of age. Wistar rats were killed at 90 days of age. Pancreas and spleen from a total of $33 \mathrm{BB}$ rats and Wistar rats were removed, snap frozen and stored at $-80^{\circ} \mathrm{C}$.

Sections from a total of 243 islets from 10 untreated BB rats, 490 islets from 23 silica treated $\mathrm{BB}$ rats and 26 islets from normal Wistar rats were analysed. In about half of the cases, the size and/or orientation of islets allowed for preparation of 12 serial sections for complete immunocytochemistry. These islets were between 100 and $300 \mu \mathrm{m}$ of mean diameter. In the remainder, 4-6 serial sections were available and stained for major histocompatibility complex (MHC) class I and II antigens. Per animal, between 5 and 14 islets could be evaluated.

\section{Immunocytochemistry}

Serial spleen and pancreas cryostat sections $(5 \mu \mathrm{m})$ were prepared and fixed in isopropanol for $10 \mathrm{~min}$ at $4^{\circ} \mathrm{C}$. After two washes with PBS ( $\mathrm{pH} 7.4$ ) containing $1 \%$ bovine serum albumin (BSA, Behring Werke, Marburg, FRG), slides were coded and incubated with 11 different monoclonal antibodies (as described in Table 1) for $60 \mathrm{~min}$ at $4^{\circ} \mathrm{C}$. After two further washes, slides were incubated with peroxidase-conjugated rabbit anti-mouse immunoglobulin (Dakopatts, Hamburg, FRG) diluted 1:25 in PBS with 5\% heat inactivated normal rat serum for another $60 \mathrm{~min}$. Sections were washed twice in TRIS-HCl buffer $(50 \mathrm{mmol} / 1, \mathrm{pH} 7.6)$ and incubated with 3'3-diaminobenzidine tetrahydrochloride $(0.5 \mathrm{mg} / \mathrm{ml}$, EGA-Chemie, Steinheim, FRG) in TRIS$\mathrm{HCl}$ containing $0.025 \% \mathrm{H}_{2} \mathrm{O}_{2}$ for $10-15 \mathrm{~min}$, and finally stained with Mayer's Haematoxylin for 1-2 min, dehydrated in a graded ethanol series and mounted. As positive control, a section from rat spleen was placed adjacent to the pancreas section on each slide and stained in parallel. For each series of islet sections, one slide was stained with second antibody only as a control for endogenous peroxidase activity. Coded slides were evaluated by two persons in a blinded manner.

\section{Electron microscopy}

Electron microscopy of islets from 3 normoglycaemic BB rats aged 69 and 70 days and 2 animals 120 days of age was done following exactly the procedure published previously [20]. Spleen adjoining pieces of pancreata were fixed with glutaraldehyde (1.25\%) and postfixed with $\mathrm{OsO}_{4}(1 \%)$ in cacodylate buffer. Tissue pieces were embedded in Spurr resin after graded ethanol dehydration. Specimen were sectioned semi-thin and screened by light microscopy for the presence of islets in the plane of section. All islet containing specimen were sectioned ultra-thin and examined by transmission electron microscopy.

\section{Statistical analysis}

Statistical analysis was performed by Student's t-test (two-sided) and by Chi-square test. The level of significance was set as $p<0.05$.

\section{Results}

Normal islets show a weak and homogeneous expression of MHC class I antigens which is stronger than in the surrounding exocrine tissue (Fig. $1 \mathrm{a}$ ). The few strongly stained cells in islets are MHC class II, W3/25 positive macrophages (Table 2, Fig. $1 \mathrm{~b}$ ).

In $\mathrm{BB}$ rats, the first alteration of islets detectable by immunohistochemistry (whether silica treated or not, see below) when compared to normal islets (i. e. Wistar rat, Table 2) was the enhanced expression of MHC class I antigen in one (peripheral) area of the islet (Fig. 1c). This site was characterised by a local infiltrate of MHC class II positive cells (Fig. 1d) which were identified as $\mathrm{W} 3 / 25^{+}-$, ED $1^{+}$-macrophages (see below); whereas B-, T- or NK-lymphocytes were almost absent at this stage (Table 2). This first detectable phase of islet inflammation was termed stage $1 \mathrm{a}$.

A more intense form of macrophage infiltration, still almost without lymphocytes, was defined as stage $1 \mathrm{~b}$. The main characteristic is the enhanced expression of MHC class I antigens all over the islet and the adjacent 


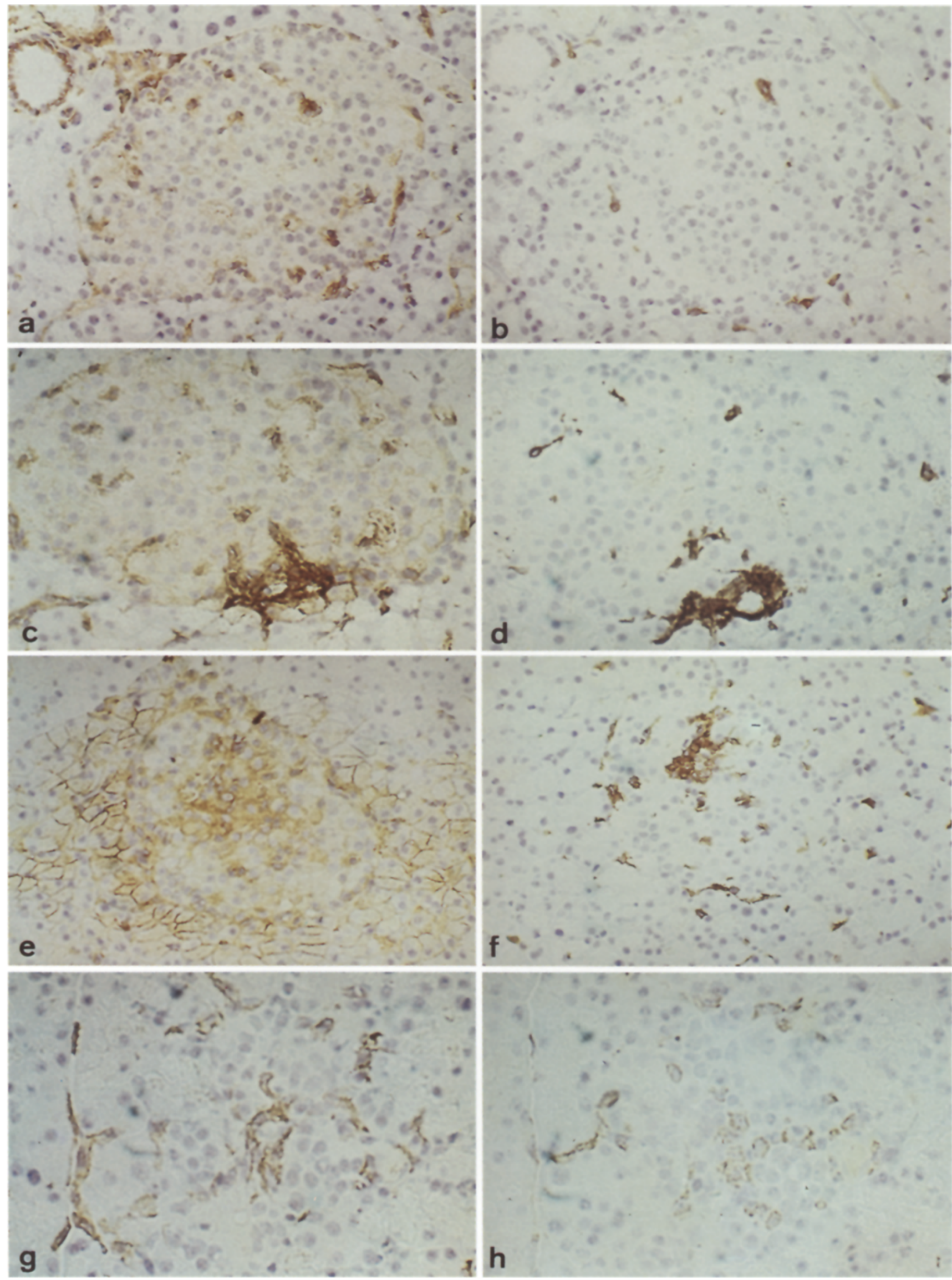


Table 2. Semiquantitative analysis of immune cells present in "normal islets" and in islets with insulitis

\begin{tabular}{|c|c|c|c|c|c|c|}
\hline \multirow[t]{2}{*}{ Antibody } & \multicolumn{6}{|c|}{ Number of cells (mean \pm SEM) stained per islet section in: } \\
\hline & $\begin{array}{l}\text { Normal islets } \\
\text { (Wistar rats) } \\
(n=8)\end{array}$ & $\begin{array}{l}\text { "Normal islets"a } \\
\text { (BB rats) } \\
(n=130)\end{array}$ & $\begin{array}{l}\text { Stage 1a insulitis }{ }^{\mathrm{b}} \\
(n=28)\end{array}$ & $\begin{array}{l}\text { Stage } 1 \mathrm{~b} \text { insulitis } \\
(n=15)\end{array}$ & $\begin{array}{l}\text { Stage } 2 \text { insulitis } \\
(n=24)\end{array}$ & $\begin{array}{l}\text { Stage } 3 \text { insulitis }{ }^{\mathrm{e}} \\
(n=17)\end{array}$ \\
\hline O×3/Ox6/Ox17 & $4 \pm 1.1$ & $6 \pm 0.3$ & $13 \pm 1.6$ & $19 \pm 2.1^{\mathrm{f}}$ & $>>20^{\mathrm{h}_{-}}$ & $>>20^{\mathrm{h}} 7$ \\
\hline $\mathrm{W} 3 / 25$ & $2 \pm 0.6$ & $6 \pm 0.3$ & $10 \pm 1.5$ & $15 \pm 2.0$ & $>20^{\mathrm{g}}$ & $>>20^{h}$ \\
\hline ED1 & $0.4 \pm 0.4$ & $2 \pm 0.2$ & $5 \pm 0.8$ & $12 \pm 1.3$ & $>20^{\mathrm{g}}$ & $>20^{\mathrm{g}}$ \\
\hline Ox8 & $<0.3$ & $0.1 \pm 0.1$ & $0.1 \pm 0.1$ & $0.4 \pm 0.2$ & $8 \pm 1.4$ & $13 \pm 2.2^{i}$ \\
\hline Ox12 & $<0.3$ & $<0.1$ & $<0.1$ & $0.4 \pm 0.3$ & $0.7 \pm 0.3$ & $20 \pm 2.2^{\mathrm{i}}$ \\
\hline W3/13 & $<0.3$ & $0.4 \pm 0.1$ & $1.2 \pm 0.3$ & $2.3 \pm 0.6$ & $7 \pm 1.2$ & $14 \pm 2.1^{i}$ \\
\hline
\end{tabular}

a Islets from $33 \mathrm{BB}$ rats were analysed and defined as "normal" when counts were indistinguishable from Wistar rat islets; ${ }^{\mathrm{b}}$ Stage $1 \mathrm{a}$ is defined by enhanced MHC class I expression at the periphery or one pole of the islet; ${ }^{\mathrm{c}}$ Stage $1 \mathrm{~b}$ is defined by enhanced MHC class I expression throughout the islet and a lack of lymphocytic infiltration; ${ }^{\mathrm{d}}$ Stage 2 is defined by infiltration of $>3 \mathrm{Ox} 8^{+}$-cells and $<3$ Ox $12^{+}$-cells; ${ }^{\mathrm{e}}$ Stage 3 is defined by infiltration of $>30 \times 12^{+}$-cells; ${ }^{f}$ In about $50 \%$ of cases, counts exceeded 20 and were assessed as either 25 or $30 ;{ }^{g}$ In about $60 \%$ of cases, counts exceeded 20 and were assessed as 25 or $30 ;{ }^{\mathrm{h}}$ In nearly all of cases, counts exceeded 20 and were assessed as 25 or $30 ;{ }^{\mathrm{i}}$ In $20-40 \%$ of cases, counts exceeded 20 and were assessed as 25 or 30

exocrine tissue (Fig.1e) with concomitant larger numbers of $\mathrm{MHC}$ class $\mathrm{II}^{+}$, $\mathrm{W} 3 / 25^{+}$, , ED1 ${ }^{+}$-macrophages (Fig. $1 \mathrm{f}-\mathrm{h}$ ) infiltrating the entire islet. Detectable T-lymphocyte numbers were still minimal with a mean of one Ox-19+ ${ }^{+}$-cell per islet section (Table 2).

Proof that $\mathrm{W} 3 / 25^{+}$-cells observed at this stage are macrophages and not lymphocytes comes from the presence of these cells in normal islets at the same number as MHC class II positive cells, from the lack of $\mathrm{Ox} 19^{+}$-cells in adjacent islet sections, from the similar

Fig. 1a-h. Immunocytochemistry of normal islets and of insulitis stages $1 \mathrm{a}$ and $1 \mathrm{~b}$. a Normal islet from BB rat no. 210, islet no.7, stained with Ox18. The islet is diffusely labelled for MHC class I antigen except for few strongly stained cells, often also staining for MHC class II antigen (see Fig. 1 b). A sharp borderline between islet and exocrine tissue is visible. Magnification $94 \times$. b Normal islet from $\mathrm{BB}$ rat no. 210, islet no.7, stained with Ox6. In this adjacent section to Figure 1 a, 6 cells stain for MHC class II antigens, in location similar to MHC class I antigen positive cells. Same magnification as Figure 1 a. c Stage $1 \mathrm{a}$ islet from BB rat no. 225 , islet no. 5 , stained with Ox18. MHC class I antigen staining is still restricted to the islet boundary, but locally enhanced labelling is noted at the periphery, also staining for MHC class II antigen (see Fig. 1d). Magnification $105 \times$. d Stage $1 \mathrm{a}$ islet from BB rat no.225, islet no. 5, stained with Ox6. In this adjacent section to Figure $1 \mathrm{c}$, a focal aggregate of MHC class II antigen positive cells in seen. Otherwise, the islet appears normal. Same magnification as in Figure 1c. e Stage $1 \mathrm{~b}$ islet from BB rat no. 253 , islet no. 1 , stained with $\mathrm{O} \times 18$. Enhanded MHC class I antigen expression is seen over the islet and also the adjacent exocrine tissue. Magnification $72 \times$. f Stage $1 b$ islet from BB rat no.253, islet no.1, stained with Ox6. In addition to the focal aggregate of MHC class II antigen positive cells, there is an increased number of stained cells throughout the islet. Adjacent section to Figure 1e, same magnification. g Stage $1 \mathrm{~b}$ islet from BB rat no. 250 , islet no.3, stained with W3 $/ 25$. Cells stained have an extend irregular cell shape, characteristic of macrophages. Round lymphocyte-like cells are not seen. Magnification $133 \times$. h Stage $1 \mathrm{~b}$ islet from BB rat no. 250 , islet no. 3 , stained with ED1. In this adjacent section to Figure $1 \mathrm{~g}$, location of macrophages is similar to $\mathrm{W} 3 / 25$ positive cells. The long cell extensions of macrophages are not imaged because ED1 stains perinuclear cytoplasmic vacuoles. Same magnification as in Figure $1 \mathrm{~g}$ distribution of $\mathrm{ED} 1^{+}$- and W3 $/ 25^{+}$-cells (Fig. $1 \mathrm{~g}, \mathrm{~h}$ ) and from the non-lymphoid appearance of $\mathrm{W} 3 / 25^{+}$ cells (Fig. 1 g, Fig. 3 f).

Furthermore, in electron microscopic studies, islet sections with macrophages as the sole infiltrating cell type were recognised (correlating with light microscopically defined insulitis stages $1 \mathrm{a}$ and $1 \mathrm{~b}$ ). A total of 17 and 9 islets of rats aged 69-70 days or 120 days of age respectively were examined by electron microscopy. Eleven islets appeared normal, 7 islets showed massive destruction and macrophage plus lymphocyte infiltration. The remaining 8 islets exhibited islet cell breakdown, mostly lysis of B cells, often endothelial cell damage resulting in collapsed capillaries and onset of fibrosis. The sole infiltrating immunocytes seen were identified as macrophages as judged by their morphology and their phagocytotic activity. Often macrophages were seen accumulated at one pole of the islet (Fig. 2a) but also scattered throughout islets (Fig. 2b). Most of the macrophages are heavily engaged in phagocytosis either of cell debris (Fig. 2c) or of whole seemingly normal B cells (Fig. 2 d). Often macrophages are accompanied by fibroblasts that secrete fibrous material into the spaces filled with islet cell debris (Fig.2).

Stage 2 of islet inflammation was differentiated from stage 1 by the presence of $\geq 30 \times 8^{+}$-cells per islet section but yet $<3 \mathrm{O} \times 12^{+}$-cells (Table 2 ). Further characteristics are strongly enhanced expression of MHC class I antigens on all islet cells and in a large area of surrounding exocrine tissue (Fig. $3 \mathrm{a}$ ). A large number of cells in islets is also positive for MHC class II antigens (Fig. $3 \mathrm{~b}$ ). Again more macrophages are infiltrating (Table 2) and significant numbers of $\mathrm{O} \times 19^{+}$-cells are noted $\left(8 \mathrm{cells} /\right.$ islet section). In general, $\mathrm{Ox} 19^{+}$-cells had the appearance of small lymphocytes whereas $\mathrm{Ox} 8^{+}$. cells mostly looked like large granular lymphocytes (Fig. 3 c, d). At stage 2, not all W3 $/ 25^{+}$-cells had the appearance of macrophages, but some resembled small lymphocytes (Fig.3 e). Labelling experiments with iso- 


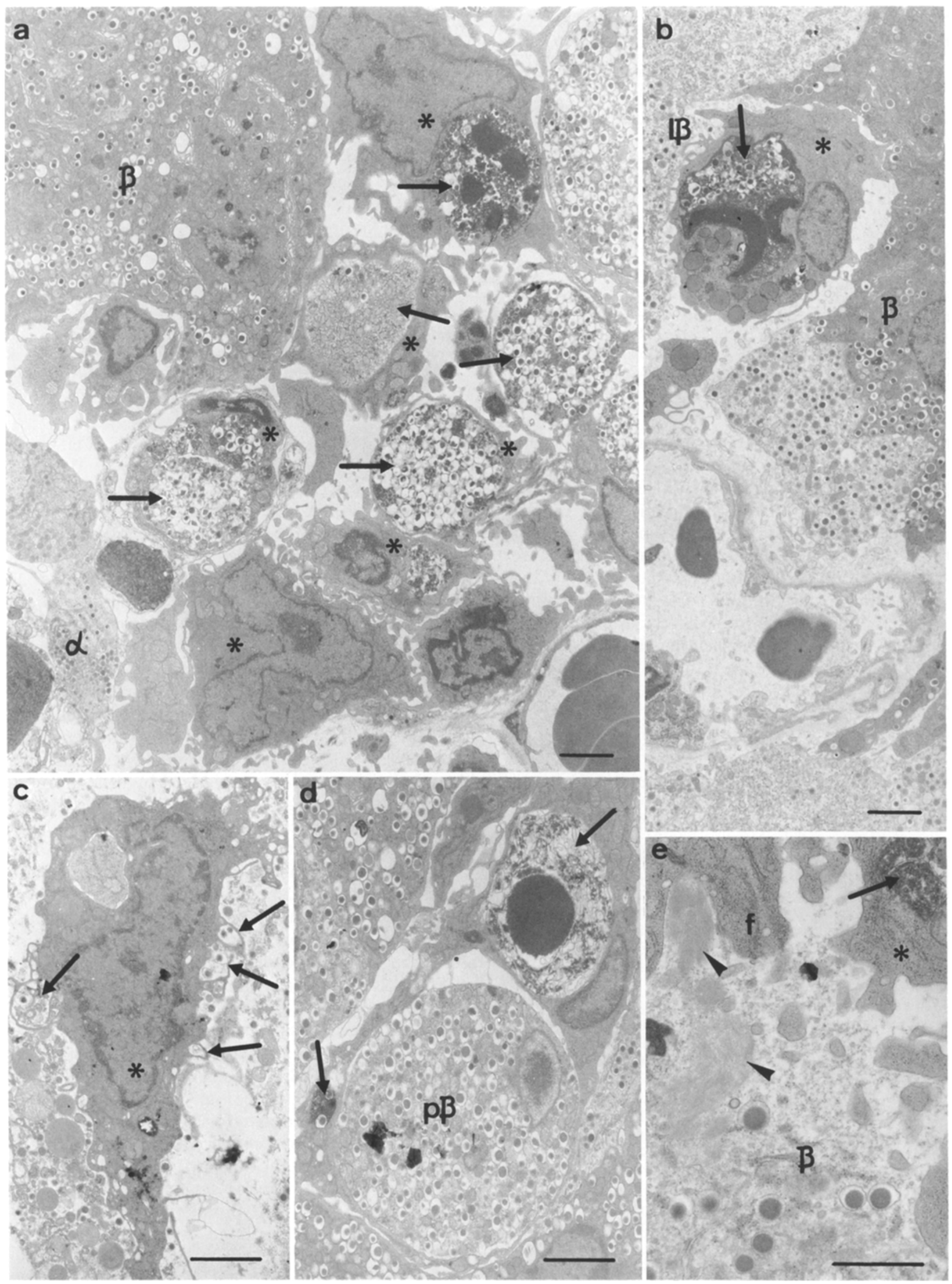


lated lymphocytes revealed that $\mathrm{Ox} 19^{+}$-lymphocytes are generally $\mathrm{W} 3 / 25^{+}$and $\mathrm{Ox} 8^{-}$; whereas $\mathrm{Ox} 8^{+}-$lymphocytes were Ox19- (data not shown) as has been reported by others $[3,21]$. Interestingly, comparatively few cells within islets stained for the ED2 ${ }^{+}$marker, characteristic of non-activated macrophages.

Stage 3 of islet inflammation was defined as islets with characteristics of stage 2 islets but additional massive focal infiltration of small round cells with intense plasma membrane staining for Ox12 (kappa light chains) and MHC class I antigens ( 3 or more Ox12 ${ }^{+}$ cells per islet section) (Fig. $3 \mathrm{f}$ ). These cells were regarded as B-lymphocytes. Although passive adsorption of immunoglobulins onto lymphoid cells has not been ruled formally out, it seems improbable here because macrophages did not stain. Furthermore, only a restricted area of the islet, and not all lymphoid cells throughout the islet, are stained. The characteristic focal concentration of small Ox- $12^{+}$-cells (see Fig. $3 \mathrm{f}$ ) could not be stained in adjacent sections for T-lymphocyte markers (not demonstrated).

In addition to 331 islets from $B B$ rats for which the complete analysis with 11 monoclonal antibodies could be performed, another 6 could not be classified according to the above scheme. All 6 islets were characterised by the absence of enhanced MHC class I antigen expression despite either positive infiltration by macrophages ( 3 cases), or by lymphocytes ( 2 cases), or by macrophages and lymphocytes ( 1 case). The parallel positive staining of MHC class I antigen in adjacent tissue and spleen sections on each slide verified the absence of enhanced MHC class I expression in these islets.

The inflammatory changes observed in pancreatic sections of $\mathrm{BB}$ rats were not restricted to islets but involved the exocrine tissue also. Inflammation was strictly focal as recognised by the regional hyperexpression of MHC class I antigens (Fig. $3 \mathrm{~g}$ ). In those areas, infiltrated immune cells stained with $\mathrm{Ox} 18, \mathrm{Ox} 3 / 6 / 17$ (Fig. 3 h), ED1, and/or W3/25 were observed. Lymphocytes $\left(\mathrm{Ox} 19^{+}, \mathrm{Ox} 8^{+}\right.$or $\left.\mathrm{Ox} 12^{+}\right)$were rarely seen. Quantitation of infiltrates was not attempted because of the focal and non-homogeneous distribution.

Fig. 2 a-e. Electron micrographs of macrophage-infiltrated islets. a A polar infiltrate of an islet from a normoglycemic BB-rat aged 70 days. The infiltrating immunocytes are easily recognized as macrophages $\left({ }^{*}\right)$ due to the massive phagocytosis they perform. $(\alpha=\alpha$-cell, $\beta=$ intact $B$ cells, arrows point to $B$ cell remnants phagocytosed). b Some islet show a scattered distribution of infiltrating macrophages $(*)$. Here a single macrophage is seen near lysed $(1 \beta)$ and intact $B$ cells $(\beta)$. The infiltrating macrophage has also phagocytosed B-cell debris (arrow, $\longrightarrow$ ). c Macrophages found in islets are often engaged in uptake of cell debris (arrows, $\longrightarrow$ ). d Some macrophages appear to phagocytose whole, seemingly intact $B$ cells $(p \beta)$ in addition to cell debris (arrows, $\longrightarrow$ ). e A macrophage $(*)$ with phagocytosed debris (arrow, $\rightarrow$ ) and a fibroblast (f) are situated near a lysed B cell (1 1$)$, the fibroblast synthesising fibrous material (arrow head, $\rightarrow$ into this space. Magnifications in a, b: $5000 \times, \mathbf{c}, \mathbf{d}: 6500 \times$, e: $17000 \times$. The bars in a-d represent $2 \mu \mathrm{m}$ and in e: $1 \mu \mathrm{m}$
Table 3. Suppression of lymphocyte and macrophage infiltration of islets after silica treatment of $\mathrm{BB}$ rats

\begin{tabular}{|c|c|c|c|c|c|c|c|}
\hline \multirow{2}{*}{$\begin{array}{l}\text { Age (days) } \\
\text { Number of } \\
\text { animals } \\
\text { treated }(n)\end{array}$} & \multirow{2}{*}{$\begin{array}{l}\text { Silica } \\
\text { treat- } \\
\text { ment }\end{array}$} & \multirow[t]{2}{*}{ Islets } & \multirow{2}{*}{$\begin{array}{l}\text { Nor- } \\
\text { mal }\end{array}$} & \multicolumn{4}{|c|}{ Islets (\%) classified ${ }^{\mathrm{a}}$ as } \\
\hline & & & & $\begin{array}{l}\text { Stage } \\
1 \mathrm{a}\end{array}$ & $\begin{array}{l}\text { Stage } \\
1 \mathrm{~b}\end{array}$ & $\begin{array}{l}\text { Stage } \\
2\end{array}$ & $\begin{array}{l}\text { Stage } \\
3\end{array}$ \\
\hline & & & & & & $37 \%$ & \\
\hline \multirow{3}{*}{$\begin{array}{r}70(n=4) \\
(n=7) \\
\end{array}$} & - & 49 & 53 & 10 & 19 & 10 & 8 \\
\hline & + & 71 & 79 & 20 & 1 & - & - \\
\hline & & & & & & $48 \%$ & \\
\hline \multirow{3}{*}{$\begin{array}{r}90(n=2) \\
(n=8) \\
\end{array}$} & - & 27 & 45 & 7 & 11 & 30 & 7 \\
\hline & + & 54 & 87 & 9 & 4 & - & - \\
\hline & & & & & & $100 \%$ & \\
\hline \multirow[t]{2}{*}{$120-150$} & - & 47 & - & - & 28 & 42 & 30 \\
\hline & + & 83 & 82 & 18 & - & - & - \\
\hline
\end{tabular}

$\mathbf{a}$ as described in Table 2

The effect of treatment of diabetes prone BB rat with silica particles on islet inflammation was determined. As shown in Table 3, islets from silica treated animals were completely devoid of lymphocyte infiltration (stages 2 and 3). Infiltration of macrophages was not totally absent but largely suppressed with an almost complete lack of insulitis stage $1 \mathrm{~b}$. The mean number of ED1 positive cells per section of islets analysed in silica treated rats was $2.6+1.7$ (SD) compared to $>20$ in the corresponding untreated $\mathrm{BB}$ rats. As described above, of 396 islets from BB rats, less than 12 sequential sections were available ( 282 from silica treated, 114 from untreated $\mathrm{BB}$ rats). These islets were classified by monoclonal antibodies $\mathrm{Ox} 3, \mathrm{Ox} 6, \mathrm{Ox} 17, \mathrm{Ox} 18$ as normal, as stage $1 \mathrm{a}$ inflammation (locally enhanced MHC class I antigen expression plus local MHC class II antigen positive infiltrate) or as stage $1 \mathrm{~b}$ inflammation (enhanced MHC class I antigen expression throughout the islet and adjacent exocrine tissue plus MHC class II antigen positive infiltrate) and further stages with lymphocytic infiltrates.

The islets from silica treated rats rarely showed MHC class I hyperexpression and MHC class II positive cells, only $1 \%$ of islets were classified as stage $1 \mathrm{~b}-3$, all other were normal $(87 \%)$ or stage $1 \mathrm{a}(12 \%)$. In contrast, of islets from untreated BB rats $57 \%$ were classified as stage $1 \mathrm{~b}-3(p<0.001)$.

\section{Discussion}

The four different qualities of islet inflammation described here are comprehensive in that only 6 out of 331 completely typed islets could not be classified according to the scheme. The 4 types of insulitis could be clearly sorted into a sequence of islet inflammation stages for the following reasons. The mildest form of islet infiltration, focal enhanced MHC class I expres- 

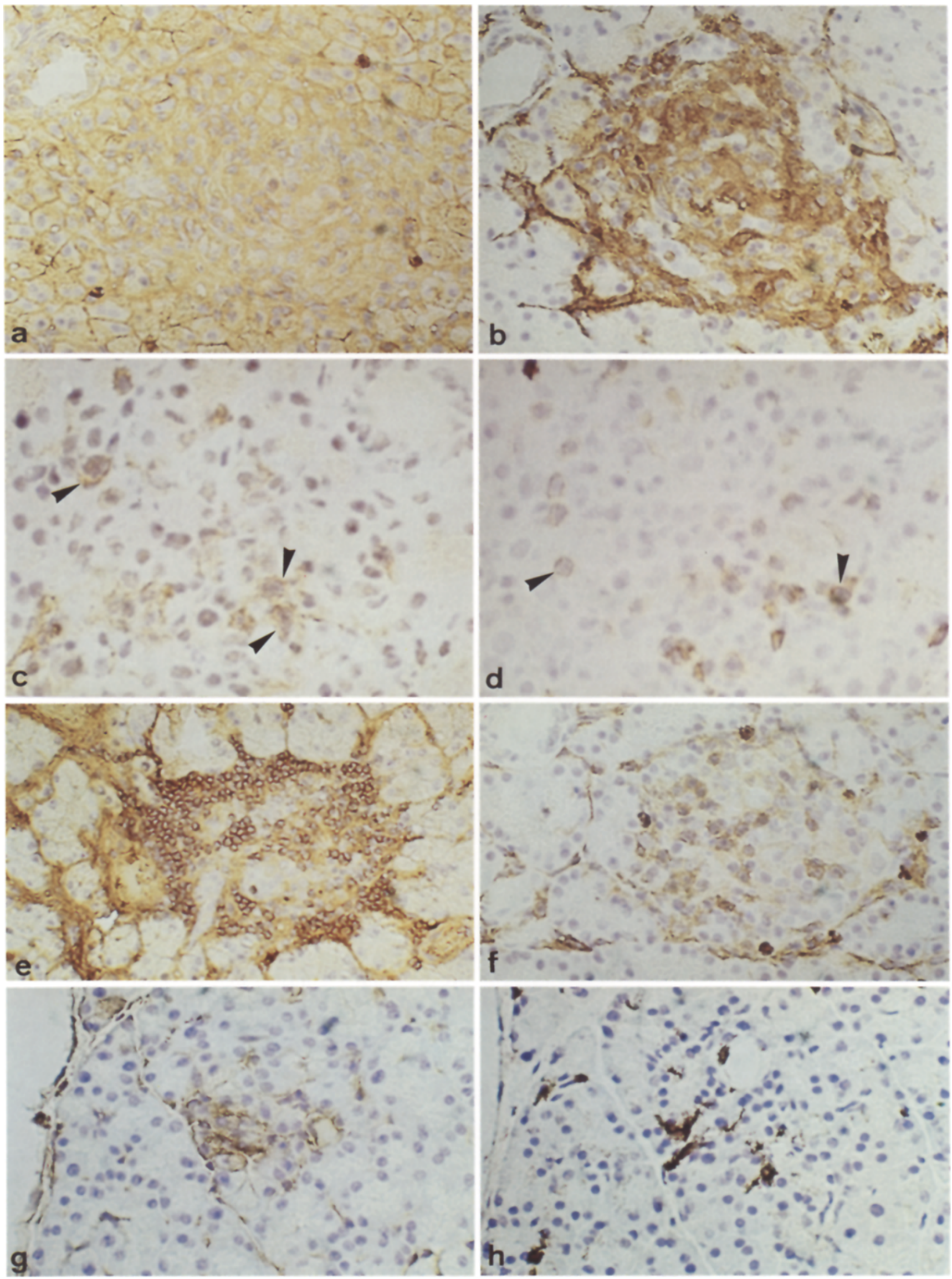
sion (stage $1 \mathrm{a}$ ) was associated with macrophage and not with lymphocyte infiltration. Lymphocyte infiltration (stages 2 and 3 ) was only seen in islets in addition to heavy macrophage infiltration. Both observations suggest that macrophages precede lymphocytes in islet infiltration. In lymphocyte infiltration, $\mathrm{Ox} 19^{+}$- and $\mathrm{O} \times 8^{+}$-cells apparently precede $\mathrm{O} \times 12^{+}$-cells because $\mathrm{T}$ and NK-cells are seen in islets in the absence of B-lymphocytes (stage 2); whereas, the reverse was never observed. These data clearly show that the natural course of islet inflammation is non-random, but that the process of insulitis follows a specific sequence of events. As shown in Table 2, BB rats of 70-90 days of age bear at the same time islets of all insulitis stages, as well as apparently normal islets, i.e., individual islets behave as independent organs. Although all stages of islet inflammation were seen in these rats, only a fraction of them would have gone on to develop diabetes. The sequence of events in islet infiltration thus may be similar in prediabetic and permanently non-diabetic BB rats.

The macrophage type present in inflamed islets has been identified as mostly ED1 ${ }^{+}$and $\mathrm{ED}^{-}{ }^{-}$. This phenotype is characteristic of activated macrophages [19] as confirmed by the electron microscopic finding that heaviliy phagocytising macrophages are found in BB rat islets, an observation that was also made by In't Veld and Pipeleers [22]. In rats, a large fraction of macrophages carry the CD4 marker [18]. A previous report

Fig. 3a-h. Immunocytochemistry of insulitis stages 2,3 and of exocrine pancreas lesion. a Stage 2 islet from BB rat no. 253, islet no. 12 , stained with Ox18. Strong hyperexpression of MHC class I antigens in islet and exocrine tissue is seen. The 4 darkly stained cells are granulocytes which are sometimes seen. Magnification $105 \times$. b Stage 2 islet from BB rat no. 253, islet no. 12 , stained with Ox17. In this adjacent section to Figure 3 a, strong expression of MHC class II antigens on the majority of cells in the islet is seen. Since a large number of macrophages are positive for insulin granula (see Fig. 2), double staining for insulin and MHC class II antigens was not attempted. Same magnification as in Figure 3 a. c Stage 2 islet from BB rat no. 253 , islet no. 12 , stained with $\mathrm{Ox} 8$. In this adjacent section to Figure $3 \mathrm{~b}$, most $\mathrm{Ox} 8^{+}$-cells appear as lymphocytes with large irregularly formed cytoplasm (arrowheads, $\rightarrow$. Magnification $122 \times$. d Stage 2 islet from BB rat no. 253, islet no. 12, stained with Ox19. In this adjacent section to Figure $3 \mathrm{c}, \mathrm{Ox} 19^{+}$-cells appear as small round lymphocytes (arrowheads, $\rightarrow$ ) with a distribution dissimilar to $\mathrm{Ox} 8^{+}$ cells. Same magnification as in Figure $3 \mathrm{c}$. e Stage 3 islet from BB rat no. 250 , islet no. 6 , stained with $\mathrm{Ox} 12$. A large number of focally aggregated small lymphocytes is seen with intense plasma membrane staining. Vessels and ducti show diffuse brown background stain. Magnification $105 \times$. f Stage 2 islet from BB rat no. 253, islet no. 12, stained with W3/25. During lymphocytic insulitis (stages 2 and 3 ), a fraction of $\mathrm{W} 3 / 25^{+}$-cells display macrophage-like extended structures; in addition, small round lymphocytes are labelled. Magnification $105 \times$. g Exocrine pancreas lesion in BB rat no.252, stained with Ox18. Focal hyperexpression of MHC class I antigens is seen. Magnification $105 \times$. h Exocrine pancreas lesion in BB rat no.252, stained with Ox17. In this adjacent section to Figure $3 \mathrm{~g}$, a number of MHC class II antigen positive cells are seen in the area of MHC class I hyperexpression. Consecutive sections showed staining for W3/25 and ED1 but not for $\mathrm{O} 8 \mathrm{8}$ and $\mathrm{Ox} 19$ (not demonstrated). Same magnification as in Figure $3 \mathrm{~g}$. on $\mathrm{BB}$ rat insulitis described the infiltration of $\mathrm{CD} 4^{+}-\mathrm{T}$ lymphocytes - many showing MHC class II expression - as the first step of islet infiltration [23]. It is by use of the ED1 marker and ultrastructural analysis that the first cells in islet infiltration could be identified as $\mathrm{CD}^{+}{ }_{-}^{-}, \mathrm{MHC}$ class II positive, ED1 positive, ED2 negative activated macrophages. These observations are in accord with two recent communications [24, 25] which qualitatively describe the presence of macrophages in $\mathrm{BB}$ rat islets during early stages of insulitis.

It is of interest that treatment of BB rats with silica not only suppresses macrophage infiltration but also lymphocytic insulitis. A qualitative analysis by Lee et al. [26] also showed the lack of lymphocytic insulitis. Macrophage infiltration was not determined. In a previous study, we could not find a direct effect of silica administration on lymphocyte subtypes nor on T-cell function in peripheral blood of BB rats [6]. We, therefore, suppose that macrophage infiltration is an essential precondition for lymphocytic insulitis.

A second point is that concomitant with the lack of macrophage infiltration is a lack of MHC class I hyperexpression in islets from silica treated rats (lack of insulitis stages $1 \mathrm{~b}-3$ ). This indicates that MHC class $\mathbf{I}$ hyperexpression is associated with macrophage infiltration of islets.

Although macrophage infiltration appears as an essential early step of islet inflammation, the contribution of $\mathrm{Ox} 19^{+}$- and $\mathrm{O} \times 8^{+}$-lymphocytes is as important for disease manifestation. This can be concluded from in vivo depletion experiments. Multiple administration of Ox19, as well as of Ox8 monoclonal antibody, was found to suppress diabetes development in BB rats [3], similar experiments to determine the contribution of B-lymphocytes have not been reported. The immunocytochemical analysis presented here indicates that B-lymphocyte infiltration is a late step which may not occur in all islets.

Another result of the present study is the observation of focally restricted areas of pancreatitis in BB rats in confirmation of an earlier report [27]. Focal pancreatitis is among the earliest recognisable changes in pancreas histology and involves vascular lesions, immune cell infiltrates and exocrine tissue destruction.

In conclusion, the present semi-quantitative analysis of immune infiltrates in BB rat islets suggests a multistep mechanism of islet inflammation with macrophage infiltration as the earliest recognisable step in the cascade of events followed by T-lymphocytes, NK-cells and finally by B-lymphocytes.

\footnotetext{
Acknowledgements. We thank L.Uebber and A.Schlömer for their help with the animal work and electron microscopy. We are grateful to Drs. V.Burkart, K. Maruta and U. Kiesel for help with BB rat breeding and silica treatment and to Dr. C.D.Dijkstra for a gift of ED1 and ED2 antibodies. We thank L. Foerster for help with preparation of the manuscript. This work was supported by the Deutsche Forschungsgemeinschaft (SFB113, B 5 and Ko806/2-1), by the Bundesministerin für Jugend, Familie, Frauen und Gesundheit and by the Ministerin für Wissenschaft und Forschung des Landes NordrheinWestfalen and by Nordisk-price grant to Dr. V.Kolb-Bachofen.
} 


\section{References}

1. Nakhooda AF, Like AA, Chappel CI, Murray FT, Marliss EB (1977) The spontaneously diabetic Wistar rat. Metabolic and morphologic studies. Diabetes 26: 100-112

2. Like AA, Kislauskis E, Williams RM, Rossini AA (1982) Neonatal thymectomy prevents spontaneous diabetes mellitus in the BB/W rat. Science 216: 664-666

3. Like AA, Biron CA, Weringer EJ, Byman K, Sroczynski E, Guberski DL (1986) Prevention of diabetes in BioBreeding/Worcester rats with monoclonal antibodies that recognize $\mathrm{T}$ lymphocytes or natural killer cells. J Exp Med 164: 1145-1159

4. Koevary SB, Williams DE, Williams RM, Chick WL (1985) Passive transfer of diabetes from $\mathrm{BB} / \mathrm{W}$ to Wistar-Furth rats. J Clin Invest 75: 1904-1907

5. Oschilewski U, Kiesel U, Kolb H (1985) Administration of silica prevents diabetes in BB-rats. Diabetes 34: 197-199

6. Kiesel U, Oschilewski M, Kantwerk G, Maruta M, Hanenberg H, Treichel U, Kolb-Bachofen V, Hartung HP, Kolb H (1986) Essential role of macrophages in the development of type $I$ diabetes in BB rats. Transplant Proc 18: 1525-1527

7. Kolb-Bachofen V, Kolb H (1983) New concept of insulitis and Bislet cell destruction. Diabetes 32 [Suppl 1]: 22A

8. Kolb H, Kiesel U, Flohr K, Greulich B, Freytag G, KolbBachofen V (1984) Cell mediated immunity to islet cells: lessions from animal studies. Behring Inst Mitt 75: 33-38

9. McMaster WR, Williams AF (1979) Identification of Ia glycoproteins in rat thymus and purification from rat spleen. Eur J Immunol 9: 426-433

10. Dallman MJ, Mason DW, Webb M (1982) The role of host and donor cells in the rejection of skin allografts by T-cell-deprived rats injected with synorgeneic T-cells. Eur J Immunol 12: 511-518

11. Brideau RJ, Carter PB, McMaster WR, Mason DW, Williams AF (1980) Two subsets of rat T lymphocytes defined with monoclonal antibodies. Eur J Immunol 10: 609-615

12. Cantrell DA, Robins RA, Brooks CG, Baldwin RW (1982) Phenotype of rat natural killer cells defined by monoclonal antibodies marking rat lymphocyte subsets. Immunology 45: 97-103

13. Hunt S, Fowler MH (1981) A repopulation assay for B and T lymphocyte stem cells employing radiation chimaeras. Cell Tissue Kinet 14: 445-464

14. Fukumoto T, McMaster WR, Williams AF (1982) Mouse monoclonal antibodies against rat major histocompatibility antigens. Two Ia antigens and expression of Ia and class I antigens in rat thymus. Eur J Immunol 12: 237-243

15. Dallman MJ, Thomas ML, Green JR (1984) MRC Ox-19: a monoclonal antibody that labels rat $\mathrm{T}$ lymphocytes and augments in vitro proliferative responses. Eur J Immunol 14: 260-267

16. White RA, Mason DW, Williams AF, Galfre G, Milstein CF (1978) T-lymphocyte heterogeneity in the rat: seperation of functional subpopulations using a monoclonal antibody. J Exp Med 148: $664-673$
17. Williams AF, Galfre G, Milstein C (1977) Analysis of cell surfaces by xenogeneic myeloma-hybrid antibodies: Differentiation antigens of rat lymphocytes. Cell 12: 663-669

18. Barclay AN (1981) The localization of populations of lymphocytes defined by monoclonal antibodies in rat lymphoid tissues. Immunology 42: 593-600

19. Dijkstra CD, Döpp EA, Joling P, Kraal G (1985) The heterogeneity of mononuclear phagocytes in lymphoid organs: distinct macrophage subpopulations in the rat recognized by monoclonal antibodies ED1, ED2 and ED3. Immunology 54: 589-599

20. Kolb-Bachofen V, Epstein S, Kiesel U, Kolb H (1988) Low-dose streptozocin-induced diabetes in mice. Electron microscopy reveals single-cell insulitis before diabetes onset. Diabetes 37:21-27

21. Woda BA, Like AA, Padden C, McFadden ML (1986) Deficiency of phenotypic cytotoxic-suppressor T lymphocytes in the $\mathrm{BB} / \mathrm{W}$ rat. J Immunol 136: 856-859

22. In't Veld PA, Pipeleers DG (1988) In situ analysis of pancreatic islets in rats developing diabetes. Appearance of nonendocrine cells with surface MHC class II antigens and cytoplasmic insulin immunoreactivity. J Clin Invest 82: 1123-1128

23. Dean BM, Walker R, Bone AJ, Baird JD, Cooke A (1985) Prediabetes in the spontaneously diabetic $\mathrm{BB} / \mathrm{E}$ rat: lymphocyte subpopulations in the pancreatic infiltrate and expression of rat MHC class II molecules in endocrine cells. Diabetologia 28: 464-466

24. Walker R, Bone AJ, Cooke A, Baird JD (1988) Distinct macrophage subpopulations in pancreas of prediabetic $\mathrm{BB} / \mathrm{E}$ rats. Possible role for macrophages in pathogenesis of IDDM. Diabetes 37: 1301-1304

25. Lee KU, Kim MK, Amano K, Pak CY, Jaworski MA, Mehta JG, Yoon J-W (1988) Preferential infiltration of macrophages during early stages of insulitis in diabetes-prone BB rats. Diabetes 37 : 1053-1958

26. Lee KU, Pak CY, Amano K, Yoon J-W (1988) Prevention of lymphocytic thyroiditis and insulitis in diabetes-prone BB rats by the depletion of macrophages. Diabetologia 31: 400 402

27. Seemayer TA, Colle E, Tannenbaum GS, Oligny LL, Guttmann RD, Goldman H (1983) Spontaneous diabetes mellitus syndrome in the Rat, III. Pancreatic alterations in aglycosuric and untreated diabetic BB Wistar-derived rats. Metabolism 32: 26-31

Received: 15 July 1988

and in revised form: 15 December 1988

Prof. Dr. H. Kolb

Diabetes-Forschungsinstitut

der Universität Düsseldorf

Auf'm Hennekamp 65

D-4000 Düsseldorf 1

FRG 